\title{
Regulating the old game of smuggling? Coltan mining, trade and reforms in the Democratic Republic of the Congo*
}

\author{
Claude Iguma Wakenge \\ Claremont Graduate University, School of Social Science, Policy $\mathcal{E}^{\circ}$ \\ Evaluation, I 7o E. I ${ }^{\text {th }}$ Street, Claremont, CA 9 I 7 I I \\ Email: claudeigumaw@gmail \\ Dennis DijKzeul \\ Institute for International Law of Peace and Armed Conflict, Ruhr \\ University Bochum, Bochumer Fenster 9B, 44787 Bochum, Germany \\ Email: dennis.dijkzeul@rub.de \\ and \\ Koen VlassenRoOT \\ Department of Conflict E् Development Studies, University of Ghent, \\ Universiteitstraat 8, gooo Ghent, Belgium \\ Email: koen.vlassenroot@ugent.be
}

\section{A B S T R A C T}

This article examines the smuggling of coltan into and out of artisanal mining areas in northern Katanga where the ITRI Tin Supply Chain Initiative (iTSCi), a policy on conflict minerals, tries to improve transparency in trading tin,

\footnotetext{
* This research was funded by the WOTRO Science for Global Development Department of the Netherlands Organization for Scientific Research. We are very grateful for the earlier comments of Prof Dorothea Hilhorst and Dr Jeroen Cuvelier and two anonymous reviewers on the original manuscript. This article is partly based on Wakenge, C.I. 2014. 'Réguler un vieux jeux? Acteurs et défis à la réforme minière au Nord-Katanga', L'Afrique des Grands Lacs, Annuaire 20I3-2OI4, pp. 223-242.
} 
tantalum (coltan) and tungsten. The article approaches smuggling from a sociology of economic life perspective, closely examining how and why artisanal miners and mine-based middlemen (négociants) helped smugglers (hiboux) in the trafficking of coltan. The findings indicate that the social networks in which miners and mine-based négociants are embedded allow the miners, négociants and smugglers to maintain close relationships and to breach official regulations, but miners and mine-based négociants also rely on the same networks to cheat in their dealings with the smugglers. This article concludes that, rather than considering coltan mining areas to be 'enclaves of regulations', understanding and addressing smuggling at both local and broader contexts call for a comprehensive, more contextualised approach.

\section{I N T R O D U C T I O N}

Nowadays, because of the International Tin Research Institute's (ITRI) Tin Supply Chain Initiative (iTSCi) regulations in trading minerals, smuggling coltan in and out of artisanal mining areas is, like witchcraft or malevolent practices of sorcery, done secretly. One cannot engage in smuggling activities with unknown persons. (Hiboux 2014 Int.)

In (post-) crisis situations and generally within societies where external policy - like the iTSCi - is enforced, people display different responses to such a policy (Mosse 2004; Colebatch 2009). In this respect, this article is primarily concerned with the smuggling of coltan, but also refers to related deceptive practices. Although smuggling goods - especially minerals - has characterised the informal economic sector in the Democratic Republic of the Congo (DRC), and neighbouring countries, for decades (MacGaffey 1991; Garrett \& Mitchell 2009), this study revisits this phenomenon, viewing smuggling as an important primary response that circumvents the iTSCi policy that has been in place in northern Katanga since 2011.

Designed in 2009 by ITRI, a private initiative that represents the tin industry and its members who are mainly mining and smelting companies, iTSCi aims to improve the 'public image' (Vogel \& Radley 2015: 409) of ITRI's members sourcing minerals in conflict-affected areas like the eastern DRC. It provides a means of determining the origin of tin, tantalum and tungsten (referred to as $3 \mathrm{~T}$ ) and documenting the trade chain of these minerals by 'tagging and bagging' their loads at the mining sites, trading posts and mineral depots. Although it is a private initiative, iTSCi is in line with official international and national mining policies (see Section 6).

Revisiting the long-standing practice of smuggling is useful for understanding the full impact of international policies addressing conflict 
minerals. This article provides an in-depth and contextualised analysis of how policies, especially iTSCi, are put in force and challenged in the eastern Congo. According to the International Peace Information Service (IPIS 2012: 10), the term 'conflict minerals' is applied to define the extraction and trade of minerals from conflict-affected areas where human rights abuses take place. Mineral exploitation, smuggling and conflict are seen as interwoven. It is often argued that artisanal and small-scale mining, smuggling minerals and conflicts allow armed groups operating in the eastern DRC to survive due to the profits they make from mining (Global Witness 2009).

This view has sparked a controversial debate among scientists and other observers (Autesserre 2012). On the one hand, policy initiatives addressing conflict minerals align with a large spectrum of reforms in mining governance aimed at fighting corruption and improving transparency of the minerals' flow in the hope of reducing conflict and building a better functioning state (Garrett \& Mitchell 2009). On the other hand, several observers point out that 'conflict-free' initiatives like iTSCi are top-down, externally driven, insufficiently in tune with one another and lack an in-depth understanding of local dynamics (Geenen 2012). While favouring a monopoly in trading minerals for certain buyers (Diemel \& Cuvelier 2015; Vogel \& Radley 2015), these initiatives are also confronted with overlapping governing authorities on the ground (Müller-Koné 2015). Given that the issue of smuggling minerals has received scant attention regarding conflict-free minerals' initiatives, this article explores by whom such initiatives, especially iTSCi, are challenged and in which manner people are actively 'resisting' it.

The iTSCi Programme aligns with both the Congolese government and international policy on conflict-free minerals in eastern DRC. Since the early 200os, the international community has urged the DRC government to reform the mineral sector, which was said to encourage various types of 'networks of conflict economies' (Utas 2012: 11), in which groups of (in)formal actors reap illegal benefits from mining that contribute directly and indirectly to conflict.

In northern Katanga, iTSCi aims to curb the smuggling of coltan. Given that the coltan business has been controlled by 'criminal actors' (Global Witness 2009), iTSCi's main objective is to improve the transparency of this business (iTSCi 2011). In addition, coltan is a mineral that has often been linked to discussions of conflict minerals in media reports and advocacy campaigns conducted by non-governmental organisations (Nest 2011: 105-9). Making the coltan trade more transparent 
would 'make an important contribution to the evolution of better governance of the sector' (Spittaels 2010: 62) and would help artisanal miners and mine-based middlemen (so-called négociants) to carry out their activities more safely and efficiently by preventing abuses by armed groups (De Koning 2010). Why, then, have these miners and négociants cooperated with coltan smugglers, undermining iTSCi's primary objective? How is smuggling actually organised and what are the motives and discourses of the people involved?

In addressing these questions, this article draws on the sociology of economic life perspective, which understands economic action to be embedded in social networks (Granovetter 1985). Based on 12 months of fieldwork conducted mainly at three artisanal mining sites in northern Katanga (Kahendwa, Kisengo and Mai-Baridi), the study analyses how social networks in which mineworkers and négociants participate facilitate smuggling and, crucially, how these networks are organised and adapt their strategies in response to iTSCi. Thus, the article builds on the argument that people adapt their strategies of negotiating policy outcomes while trying 'to make policy fit their own perspectives of the problem and goals' (Hilhorst 2013: 8).

This article is organised as follows. The next two sections discuss the theoretical framework and elaborate on the methods of data collection and analysis. We then briefly introduce the local and historical context of $3 \mathrm{~T}$ mining and the coltan trade in northern Katanga. This is followed by an outline of the significance of coltan smuggling in the study areas. The next section discusses the policy regarding smuggling and the organisation of the coltan trade under iTSCi. This is followed by an explanation of the modus operandi of miners and négociants in liaising with and deceiving the smugglers. The final section discusses the main outcomes of this article.

\section{THEORISING INFORMAL ECONOMY AND SOCIAL NETWORKS}

The sociology of economic life school builds on the assumption that economic action is linked to or depends on actions and institutions that are non-economic in content, goals and processes (Granovetter 2005: 35). This theory is important for understanding how debates on the informal economy, of which smuggling is an integral part, have evolved in SubSaharan Africa.

The informal economy, consisting of 'economic activities taking place outside the framework of the state' (Meagher 2010: 12) has been 
documented extensively in many parts of Sub-Saharan Africa since the end of the 1980s (MacGaffey 1991; Reno 2000; Raeymaekers 2009). Several studies on the informal economy have investigated the smuggling of minerals specifically (Deardorff \& Stopler 1990; Hilson \& Potter 2003; Vocke \& Oomes 2003). Scholars have shown that the growth of an informal and 'invisible economy' (Meagher 2010: 6) allows people to respond to state failure in service provision.

In the 199os, social networks gained prominence in social science research. Working with this concept enables the tracing of informal organisational processes (Meagher 2010: 23), and it has since been used to examine smuggling (Meagher 1990) and other forms of behaviour (including corruption) that violate the laws or regulations of the state. Many authors have argued that, in the absence of efficient economic markets, kinship-based and trust-based relations between people - especially sellers and buyers - and their networks play a key role in economic life (Granovetter 1985; Hart 1988; Titeca \& De Herdt 2010).

Opinions differ on whether social networks are beneficial in the context of economic development. Some scholars have asserted that people use social bonds or support networks to access resources and to foster a 'logic of self-protection' (Vlassenroot et al. 2016: 17). Other researchers have stressed that social networks are detrimental to economic development, arguing that these networks foster social liabilities and encourage predatory or criminal activities such as protection rackets, drug trafficking and smuggling (Bayart 2000; Reno 2000; Roitman 2001).

Smuggling and cheating behaviours can be approached in multiple ways in terms of how they are perceived by social actors. Olivier de Sardan (2015), for example, has argued that these practices have variable legitimacies. They can take place in a hidden or open manner 'without anyone taking offence at them' (Olivier de Sardan 2015: 26). In their seminal study on cross-border trade and practical norms in Uganda's West Nile region, Titeca \& De Herdt (2010: 582), referred to a kind of 'moral economy of smuggling' that is strongly legitimised by the local populations in reaction to the abandonment of the region by the central state. Kibreab (2004), in his study on cheating behaviours among refugees in the Horn of Africa, found that refugees did not see cheating as dishonest as long as it concerned aid institutions.

The above literature points to various types of networks, created in different contexts and for diverse ends, including for the purpose of smuggling. Although it does not explain how smuggling networks may adapt 
and change their strategies in response to external intervention (such as iTSCi policy), there has been significant interest in analysing how smuggling practices breach 'formal regulations', predominantly those of the state or those set by 'formal' institutions such as aid agencies (Kibreab 2004). The present study explores the manner in which people 'resisted' iTSCi, showing how miners and négociants used social networks both for breaching its 'formal' regulations and for cheating in their dealings with 'informal' smugglers.

Using an approach grounded in the sociology of economic life to investigate coltan smuggling is useful in two ways. First, it facilitates the analysis of the details of why and how networks are structured around specific social actors and which non-economic factors help these networks to emerge and persist. Second, it helps situate smuggling and cheating practices around coltan in the local context, examining the meaning of the policies and practices for the people involved.

Analytically, this article aligns with the concept of 'networks of conflict economies', coined by Utas (2012). In many instances, Utas's concept can also be applied to post-conflict economies, such as the study areas dealing with and recovering from conflict. After all, despite numerous peace accords, the DRC experiences ongoing (armed) conflicts (Vlassenroot et al. 2016). In his study on African conflicts and transborder networks, Utas argued that 'networks of conflict economies' are very wide, ranging from neighbourhoods and cities, to rural areas, to the national and transnational level. They frequently, but not always, operate clandestinely, if not illicitly (Utas 2012: 11). He described trans-border networks as groups of actors connected for economic, political or war agendas, and as complex, dispersed over geographic space, operating under the control of 'big men' and based on 'social relations' (Utas 2012: 8).

Although Utas mainly studied trans-border dynamics, his concept of networks of conflict economies was useful for the present study. In addition to looking at networks 'from an actor-centred perspective' (Utas 2012: 11), his approach tallies with the sociology of economic life approach, which focuses on analysing economic activities as cultural, contextual and political phenomena rather than being purely based on rational actors' economic decisions (Granovetter 1985; Beckert 2007). Additionally, it is interesting to explore how networks around coltan smuggling have adapted to iTSCi. This is important given that networks are not static or monolithic and can operate at different levels of society (i.e. local, provincial, national, regional and international) (Twijnstra et al. 2014; Diemel \& Cuvelier 2015). 
Utas (2012: 13-14) identified four factors to consider when studying networks of conflict economies: (i) the degree of power that individual 'big men' invest and the resources they possess; (ii) the clandestine and unstable character of networks, which can make them efficient, flexible and adaptable to new functions; (iii) the fact that networks cut across social and economic groups, as well as geographies; and (iv) that these networks may also involve 'criminal actors'.

By discussing these factors, this article contributes to the sociology of economic life literature, demonstrating that miners, mine-based négociants and smugglers adapted their smuggling strategies in response to iTSCi. However, contrary to Utas's argument, these networks were not just under the control of 'big men' but also involved less powerful actors, such as ordinary miners.

\section{METHODS}

This article draws on qualitative fieldwork undertaken from June 2013 to March 2014 and continued in January 2015. The fieldwork followed a multi-sited ethnographic approach (Marcus 1995) in northern Katanga (at the three mining sites: the Kahendwa, Kisengo and MaiBaridi mines), in the city of Kalemie, and in South Kivu in the cities of Uvira and Misisi. Data were collected through observing how mineworkers extracted, processed and sold coltan to négociants, and through in-depth individual interviews, group interviews and informal conversations with miners, négociants and 'clandestine négociants' (smugglers) of coltan (known as hiboux - literally, owls). In total, nearly 300 artisanal miners and 21 négociants participated in this study.

Gathering reliable data on smuggling is difficult, given the lack of official statistics on this practice, corruption and the concealing of information on it. Heemskerk (2005: 84) has contended that, 'because of their lack of confidence in the good intentions of the government and researchers, miners may not reveal that they sell their product outside legal channels, and violate other regulations'. For this reason, gaining trust and collecting accurate empirical data among this population required a multifaceted approach (Ellis \& MacGaffey 1996: 25) and a long-term period of fieldwork in mining areas, urban locations and areas where hiboux travelled.

Marcus (1995: 106-8) has proposed that, when doing multi-sited ethnography, one should 'follow people and things'. In line with this approach, the first author followed 11 hiboux in various locations, 
which was challenging. Smuggling is characterised by great secrecy. Other challenges were related to the geographic space this study covered and how nimbly these individuals operated across this space. Additionally, as noted in related studies (Titeca \& De Herdt 2010: 574), interviewing people such as hiboux regarding their activities can put researchers in the position of dealing with hidden and very sensitive issues such as bribes. When seeking such data, the first author repeatedly explained to the research participants about the type of questions he was going to ask, promised to maintain confidentially and to protect their privacy, and assured the participants that the data were being collected for academic purposes. The data were not shared with any third party.

With the help of local research assistants, the first author first identified and contacted hiboux in Uvira, Misisi and Kalemie. Prior to iTSCi, these people had traded coltan in northern Katanga and were based in these cities, located roughly $180-25^{\circ} \mathrm{km}$ from the coltan mines. These hiboux were then asked whether they still had activities or 'contact persons' (antennes) in the mining areas and if they could refer the first author to them. After explaining the research objectives, regularly meeting with these hiboux and probably aided by the fact that many of these hiboux were from South Kivu, the first author's native province, he progressively gained their consent and trust to gather information on their activities, and they began to provide crucial data in a forthright manner. Of 16 hiboux initially met in Uvira and Misisi, 11 agreed to provide information on their antennes among which 9 were based in the coltan mines and 2 in Kalemie. Once there, the first author searched for these people and conducted multiple interviews with them. He then cross-checked the data by comparing them with those from the initial hiboux based in Uvira and Misisi.

Other interviewees included 5 iTSCi field staff in Nyunzu and Kalemie, 7 civil servants in the division des mines (mining service) and 12 of intelligence agencies, such as the National Intelligence Agency (Agence Nationale des Renseignements, ANR) and Détection d'Activités Militaires Anti-Patrie (DEMIAP); inspectors of investigation in the division des mines/Kalemie and the mining police (Police des Mines et Hydraucarbures, PMH) were also interviewed. Many civil servants, who were appointed in mining areas to perform the iTSCi 'tagging and bagging', worked along hiboux' trading routes or in urban areas hosting coltan black markets. 
4. LOCAL CONTEXT OF 3 T MINING AND THE COLTAN TRADE

In northern Katanga, 3 T mining - especially tin - began in 1932. Until 1960 , Géomines was the sole industrial company established in the Manono territory (central part of Katanga). After the Belgian Congo (now the DRC) gained independence in 196o, Congo-Etain (renamed Zaire-Etain in 1973) replaced Géomines until 1995, when it ceased operations (De Koning 2010). In 2007, several deposits of coltan were also discovered in the Manono, Kalemie and Nyunzu territories. In December 2014, the Kalemie office of division des mines estimated that there were a total of almost 6,ooo artisanal miners working in Nyunzu and Kalemie (Boniface Kyungu 2013 Int.). Among these miners, around 2,39o extracted coltan in eight mining sites (iTSCi-Katanga mining list; iTSCi 2013).

Before iTSCi, the coltan trade was predominantly informal and opaque in the study areas. Many coltan négociants originated from North Kivu and South Kivu. They were 'big men'. Connected to regional buying houses (so-called comptoirs), many among these négociants of Bashi and Nande ethnic groups gained their wealth from trading coltan from the study areas to North and South-Kivu. Through various intermediaries, these négociants transported the mineral by air, roads or boats to the cities of Bukavu and Uvira (South-Kivu) and Goma (North-Kivu). Their activities were closely interwoven with a web of cartels and traders, who engaged in smuggling, an activity that has deep historical roots in the DRC (MacGaffey 1991), including in northern Katanga and South-Kivu (Spittaels 2010: 17).

5. SIGNIFICANCE OF COLTAN SMUGGLING

This section explains the importance of coltan smuggling in the three mining areas. Hilson and Potter (2003: 241) have pointed out that illegal mineral sales are most rampant in contexts where governmental control of the mineral sector tends to be excessive. The smuggling practices described further (Section 7) provide evidence of this.

Although iTSCi contributed significantly to tracing the flow of coltan (Section 6.2), cases involving smuggling were found. Some of these cases - for instance the theft on 16 August 2013 of $1,400 \mathrm{~kg}$ of coltan at the Kalemie-based depot of Minserve (a trading house) - occurred outside of mining areas, making it difficult for iTSCi to address them. Additional cases involving smuggling were also reported, for instance the vrages (or fausses matières) mixed by miners and négociants with 
genuine coltan (see Section 7.1). Although it is difficult to estimate the total amount of vrages in circulation, in December 2013, the Kisengo police station intercepted $\sim 775 \mathrm{~kg}$ of vrage brought into Kisengo at checkpoints. From January to December 2013, the Kisengo police also intercepted $965.3 \mathrm{~kg}$ of smuggled coltan. According to one iTSCi field staff member, five cases of smuggling were reported in Kahendwa from February to September 2013 (iTSCi staff member a 2013 Int.). Meanwhile, many sources mentioned that $\sim 6,400 \mathrm{~kg}$ of smuggled coltan reached Uvira via Misisi that year (Civil servants b 2013 and 2014 Int.; Hiboux b 2014 Int.). In 2015, the provincial office of the National Commission against Mineral Contraband (Commission Nationale de Lutte contre la Fraude Minière) reported that 6o tonnes of smuggled tin, tungsten and coltan were intercepted in Bukavu in 2015 (Radio Okapi 2016). Although one cannot conclude that all of this coltan originated from the northern Katangese region, given the historical coltan production in North and South Kivu (De Failly 2001), scrutinising their tantalum concentration led many civil servants in the mining service in Uvira to believe that most of it did originate from northern Katanga (Civil servants b 2013 Int.).

\section{POLICING SMUGGLING AND THE COLTAN TRADE}

\section{I. iTSCi in a regional smuggling framework}

Although it was designed by the mining industry, iTSCi is part of a regional governmental framework aimed at curbing contraband minerals in the African Great Lakes Region. This framework aligns with the conflict-free mineral policy narrative, following the idea that Congolese minerals finance violent conflicts (Autesserre 2012). To improve the security situation in eastern DRC and to contribute to state-building, improved transparency in trading $3 \mathrm{~T}$ (and gold) is expected to cut the assumed ties between mining, violent conflicts and the involvement of warmongers in the mining business.

In pursuit of this aim of greater security, efforts to address mineral smuggling have been implemented at the regional and domestic levels. This first took shape in Lusaka, Zambia on 15 December 2010 , when 11 presidents of member states of the International Conference of the Great Lakes Region (ICGLR) signed the Lusaka Declaration of their Special Summit to Fight Illegal Exploitation of Natural Resources in the Great Lakes Region. In November 2013, the ICGLR created a regional anti-fraud committee. A first meeting of this committee was 
held in Kinshasa on 17-18 April 2015, gathering ICGLR's state agencies in charge of dealing with fraud and mineral contraband across the member countries. Additionally, on 20 October 2010, the DRC's government created a national commission against mineral contraband (decrees no. o719/CAB.MIN/MINES/o1/2010 and no. 140/CAB. MIN/INT.SEC/2010) and iTSCi has also been expanded to neighbouring countries, namely Rwanda (June 2011) and Burundi (May 2014).

\subsection{Anti-smuggling provincial measures}

In Katanga and South Kivu, addressing smuggling has been an official priority of the provincial governments since the end of 2009. In October 2009, the governor of Katanga, Moise Katumbi Chapwe, raised administrative charges to US\$5 per $\mathrm{kg}$ on the transit of cassiterite and its by-products, including coltan, from the Katanga province to any other province. This measure aimed to discourage the sales of Katangese minerals to other provinces, such as South-Kivu. Similarly, on ${ }_{5} 5$ August 2013, Marcellin Chishambo, the governor of South Kivu, raised the frais rémunératoires, a tax paid by licensed négociants, from US\$0.20 per $\mathrm{kg}$ to US\$3 per $\mathrm{kg}$ of coltan and from US\$0.01 to US\$0.50 per $\mathrm{kg}$ of tin (decree no. 13/030/GP/SK). Although it was also intended to control contraband minerals, the main purpose of this measure was to increase provincial tax revenues from mining.

The above measures, combined with a ban on mining activities in North Kivu, South Kivu and Maniema from September 2010 to March 2011 (Geenen 2012) and the prominent role of the Katangese policy network in establishing the iTSCi (Diemel \& Cuvelier 2015: 154), led iTSCi to expand to Katanga in 2011 and has been the most concrete initiative implemented in $3 \mathrm{~T}$ mines. By the end of 2014, iTSCi was being put into action in 471 mining sites in eastern DRC, including 232 located in Katanga. As a result, iTSCi has made a huge contribution to improving the $3 \mathrm{~T}$ trade by making it more transparent. Before iTSCi, Spittaels (2010: 17) notes that 'the comparison of data [between northern Katanga and South-Kivu] suggests large-scale smuggling. Statistics from the Mining Division in Kalemie show 30 tonnes of coltan shipped from Tanganyika to the Kivus in the first three months of 2010'. Yet, from 2011 to 2013, 1,000.53 tonnes of coltan (mainly extracted in the three study sites) and $15,561.99$ tonnes of tin were exported from Katanga (Diemel \& Cuvelier 2015: 158). According to the 2014 report from the division des mines, Kisengo alone produced 
284 tonnes, officially exported from Kalemie by Mining Mineral Resources (MMR), a trading house that had been established by an Indian business in 2010.

\subsection{Trading coltan under iTSCi}

By 1 April 2011, iTSCi had transformed the coltan mining areas of Nyunzu and Kalemie from free spaces where négociants purchased coltan independently into 'enclaves of regulations'. These refer specifically to closed spaces (the mining areas) where iTSCi 'procedures and organisational structures' (Olivier de Sardan 2015: 1) of the coltan market are applied. Practically, iTSCi worked closely with trading houses (such as MMR) and mining cooperatives (Wakenge \& Hilhorst 2017), which provided financial and technical support to miners and négociants (Figure 1). Although these trading houses and cooperatives had entitlements over $3 \mathrm{~T}$ mines (i.e. mining titles or trading licences), they could only purchase coltan under iTSCi regulations. For instance, iTSCi field staff divided each mining area into sectors, subsectors and sites composed of several tunnels (chantiers), allowing them to establish selling points (postes d'achat) within each site. No minerals from another site could enter into a site or be traded there. iTSCi field staff monitored, on a daily or weekly basis, the sale of coltan under iTSCi's 'tagging and bagging' system. In the mines, the iTSCi system consists of putting tags on bags with minerals and data recording on iTSCi log books. iTSCi staff also helped civil servants in the division des mines to record mineral statistics. The cooperatives' staff collected mineral loads and proceeded to the 'remise', an operation consisting of handing over the mineral loads to the trading houses' counting office where the minerals were processed and bagged again, before being exported to the international market. All of these measures were meant to break up the existing networks of the informal coltan trade.

iTSCi has faced criticism. From its inception, it has been an externally driven intervention led by ITRI. Moreover, according to some observers, iTSCi has not totally eradicated informal mineral trafficking and failed to address problems associated with illegal taxation in which elements of the Congolese army were involved (Global Witness 2010). Other studies point out that iTSCi has been a technical solution to complex problems of the mineral sector. IPIS (2012: 38) for instance, argues that, not only has iTSCi disrupted local livelihoods, but it did little to improve social and environmental standards and, in a certain way, has 


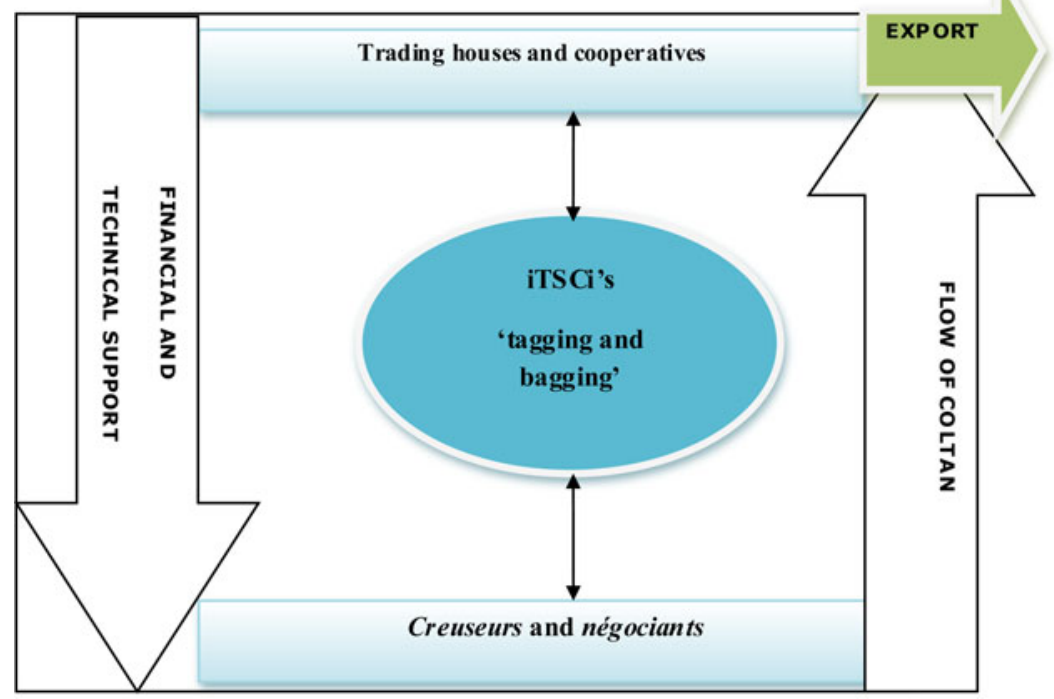

Figure 1. iTSCi's role in the coltan supply chain. Source: Primary data collected in $2013^{-2014}$.

even become a source of discrimination between powerful and less powerful economic actors sourcing minerals under the mantel of the 'tagging and bagging' system.

\subsection{Addressing smuggling under iTSCi}

By 2011, iTSCi had made significant strides towards addressing smuggling. First, iTSCi field staff monitored the 'tagging and bagging' of coltan. They also completed 'incident reports' related to four categories of practices: (i) cases of smuggling and issues related to 'tagging and bagging', for instance mistakes in data recording; the loss, damage and disappearance of tags; or recording higher than accurate weights for parcels of coltan; (ii) acts of corruption; (iii) acts of harassment, such as illegal taxes; and (iv) acts of insecurity and human rights abuses committed against miners, négociants or other people by any entity in a position of authority.

'Incidents' involving smuggling were repeatedly reported. However, these reports were 'confidential' and kept secret. In the eyes of iTSCi field staff members, this secrecy prevented them from confronting people who were directly or indirectly involved or suspected to have 
caused these 'incidents'. In 2013, the Nyunzu-based iTSCi field coordination office completed approximately 20 incident reports monthly, of which $5^{-7}$ concerned smuggling. In 2014 , there were only four reports on smuggling. This indicates an important trend towards a reduction in smuggling coltan.

Reporting and addressing 'incidents', including those involving smuggling, followed three steps. Reports were first sent to iTSCi senior staff members in Kalemie or Lubumbashi. Then, these senior staff members contacted and eventually called in state officials or senior staff members of the mining cooperatives and trading houses, asking them to address those 'incidents' in which their staff members were allegedly involved in cooperating with hiboux, dishonest mineworkers or mine-based négociants. The senior staff could then suspend them, warn them or terminate their employment.

Smuggling was also addressed during meetings of the follow-up committees (Comité Local de Suivi, CLS), which were created at the instigation of iTSCi. Gathering staff members from iTSCi, the trading houses and cooperatives, together with miners' representatives, négociants and state officials, the CLS were held monthly in either Nyunzu or Kalemie. However, CLS meetings were often delayed for financial reasons or because many participants were unavailable. iTSCi staff reported that:

During the meetings, people or entities incriminated in smuggling coltan were often absent. Those who participated in these meetings felt offended when cases of smuggling involving their staff were publicly discussed. In many instances, although people participated in these meetings, their agenda was sabotaged. (iTSCi staff members b 2013 Int.)

Addressing smuggling also aligned with legal requirements. According to Congolese mining law (Art. 300-303), smugglers are to be arrested, the smuggled and intercepted minerals are to be sold, and the amount earned is to be deposited into a national treasury bank account. In Nyunzu and Kalemie, no cases were documented in which the smugglers were arrested (iTSCi Field coordinator 2014 int.). Rather, public prosecutors' departments seized parcels of coltan and sold them to trading houses, which 'tagged and bagged' them according to the iTSCi system. However, the profits from these sales were embezzled by the representatives of the public prosecutors' departments (Civil servants c 2013 Int.).

Overall, iTSCi has clearly been an important mechanism to counteract smuggling. However, in the view of some miners and mine-based 
négociants, iTSCi field staff members' work had an accusative character. Négociants working for the Cooperative des Artisanaux Miniers du Congo (CDMC) stated:

In reporting and denouncing smuggling of coltan or any other illegal practice regarding the coltan's trade, iTSCi field staff members are so fast to accuse us. Thus, if we inform them about everything we do for instance regarding our sales of minerals to hiboux, their reports threaten to cause us to be fired from CDMC, making us jobless. (Négociants b 2013 Int.)

Hence, iTSCi was not perceived in a positive way, especially in terms of addressing smuggling. The sentiment expressed by the négociants above also reveals fears about the consequences of total transparency in fully embracing the iTSCi system. This also confirms that (international) policy, as well as humanitarian and development interventions, can generate unintended outcomes. Their rules, norms and principles are reinterpreted through interactions among various social actors (Dijkzeul \& Wakenge 2010).

7. SMUGgling COLTAN: PRACTICES, ACTORS AND MOtives

Utas (2012: 13) has argued that, given their clandestine and unstable character, networks of conflict economies become flexible, adopting new functions. The present examination of the use of fake minerals and the smuggling of coltan is highly relevant, because these were also the most reported practices in other $3 \mathrm{~T}$ mining areas in northern Katanga. Following Utas, we pay special attention to explaining how these practices, as well as the actors and networks involved, adapted to iTSCi regulations.

\section{I. Vragage}

Examining the practice known as vragage, it becomes clear that the belief that the coltan business can be perfectly 'cleaned' is inaccurate. Etymologically, vragage comes from vrac, a French term meaning something left in a jumble. Similarly, miners and négociants used the term vrages to refer to fake minerals, worthless stones (sometimes called fausses matières or faibles matières), and the by-products of coltan or similar minerals, such as tin, which were often used for cheating or smuggling.

Basically, the vrages were found only in certain places. They entered into the coltan mining areas through two main sources. First, the 
hiboux transported vrages from often remote $3 \mathrm{~T}$ mines in northern Katanga, mostly those where iTSCi was not yet implemented or had been suspended, making it difficult for cooperatives to operate. In reality, iTSCi was not implemented in all areas, because certain mines faced a depletion of minerals, were less productive or the coltan produced there had a low concentration of tantalum (e.g. Kilunga). In collaboration with drivers or local motorbike transporters, the hiboux concealed parcels of vrages on trucks, in the reservoirs of motorbikes, in oil drums, and in sacks of charcoal and maize that were brought into coltan mining areas.

Second, vrages came from the maman muturuse, a group of women who processed coltan before it was sold by mineworkers at the selling points. After heating the coltan, the maman muturuse separated the genuine coltan from the by-products. The latter were rarely thrown away, leading people to believe that mineworkers and négociants used them afterwards as vrages.

Selling vrages was cleverly organised. This process took place in private houses or in the bush rather than at iTSCi selling points. Many hiboux had local clients-predominantly miners or mine-based négociants. They were not chosen by happenstance. During many informal conversations with the hiboux, they noted that their clients were not only linked through economic relationships (Hiboux a 2014 Int.). Rather, their ties were, in one way or another, kinship and/or trust-based (Hart 1988).

These clients fulfilled various tasks and used the vrages for diverse ends. They were able to inform the hiboux about the evolution of mining activities, the current coltan prices and the local security situation - for instance, the places where the mining police had erected checkpoints. Clients purchased vrages themselves and also helped the hiboux to sell them to other mineworkers or to mine-based négociants. In the second half of 2013 , one $\mathrm{kg}$ of vrage cost around US\$15 in Kisengo and Kahendwa, approximately half the price of genuine coltan set by CDMC and the Cooperative Minière Maendeleo, which was US\$40 in Kisengo and US\$28.80 in Kahendwa.

Vrages were also used for mineral-producing ends and coltan trade. Mineworkers introduced vrages into their chantiers during the production phase. They mixed these vrages with the mineral sand found there to inflate the site's productive potential. Mineworkers also mixed vrages with the coltan sold to négociants. In addition, sous-couverts (lower-level mineral buyers often appointed by négociants at selling points mostly on the basis of trust relationships) used vrages to augment the quantity of minerals purchased and introduced these vrages in the purchases of 
négociants. This implies that négociants also used vrages before they handed over their parcels of minerals to the cooperatives (and these to trading houses) who were thus losing out. Even though the vragage was prohibited by iTSCi, none of the informants in this study denounced it.

Three explanations account for why vragage took place. First, this practice stemmed from the local organisation of the coltan market, which provided strong incentives for cheating and price evasion because of the monopoly of certain actors like MMR, who set prices of coltan that were continuously contested by mineworkers and négociants (Wakenge \& Hilhorst 2017). Also, given the limited production of coltan, the largest coltan trading house and cooperative - MMR and CDMC - did not purchase tin in Nyunzu and Kalemie; consequently, tin was mostly used as a vrage in these territories. Additionally, iTSCi was the only reform initiative implemented in the areas, and mining activity continued in those areas where iTSCi did not expand or was halted, as it was in Kilunga. However, mineworkers in these areas had no one to sell to unless their mineral or their vrages were purchased by hiboux who were capable of marketing them elsewhere, for instance in the Kahendwa or Kisengo mines.

Second, cheating and the smuggling of vrages resulted from the management policies of most trading houses and cooperatives. As mentioned above, there were significant variations in the prices set for coltan between and within the mining areas, depending on the concentration of tantalum. For instance, in late 2013, the price variation between Kisengo and Kahendwa approached $30 \%$, pushing many mineworkers, local négociants and hiboux to search for promising market opportunities in Kisengo.

The third explanatory factor for the use of vrages is their role as a source of income. Négociants reported:

When we mixed $10 \mathrm{~kg}$ of genuine coltan with $1.5 \mathrm{~kg}$ of tin or other fausses matières, we sold this mixture to the CDMC's négociants. This operation took place at any time after purchasing coltan from miners and our income from this deal raised from US $\$ 288.80$ to an average of US $\$ 331.20$ per $10 \mathrm{~kg}$. (Négociants a 2013, $2014 \mathrm{Int}$.)

All three reasons for vragage indicate that people have room to manoeuvre with cheating or smuggling coltan.

\subsection{Hiboux}

The relatively uncontrolled nature of the coltan trade can also be seen when looking at the smuggling activities of the hiboux. These clandestine 
négociants either operated through local antennes or moved to coltan mining areas from other mining areas, urban cities or other provinces (e.g. from South Kivu to northern Katanga). Of the 11 hiboux followed in the present study, 9 operated through antennes who were their close relatives. The other antennes were people with whom the hiboux had collaborated for years. Both groups built up their relationships gradually (Geenen 2016: 113-16). Given the hiboux's mobility, dispersed throughout the study area and using local connections, it was difficult to estimate how many hiboux there were, or how and when they formed their networks. Utas (2012:10) has argued that networks of conflict economies are important to analyse but hard to pin down with precision. At the end of 2013, the Kisengo police station estimated that around 21 hiboux were smuggling coltan in Kisengo alone (PMH chief and ANR staff members 2014 Int.).

Although the trading houses, cooperatives, state agencies and mining police treated hiboux as illegal mineral buyers, the hiboux regularly visited coltan mines and their adjoining villages. Mine-based négociants of Kisengo and Mai-Baridi who worked for CDMC made the following comment: 'When we see some faces of people known as hiboux coming to the mines, we guess that coltan prices have increased somewhere' (Négociants a 2014 Int.). In addition, four hiboux noted:

We often visited Kisengo and Kahendwa, where trading houses, cooperatives and iTSCi were unable to adjust coltan prices like in the cities. Once there, we would hide to avoid being seen by their staff, but we knew people to talk to in order to buy coltan. (Hiboux c 2013 Int.)

Together, the above statements suggest two interesting elements. First, coltan mining areas were not virgin territory for many hiboux; rather, locally based négociants, their antennes and hiboux know each other well. They not only had economic exchanges but were also embedded in 'networks of social relations' (Granovetter 1985: 490). Such social relations between traders have been documented earlier in the DRC. In their study on trade networks between Congo and Paris, MacGaffey \& Bazenguissa-Ganga (2000: 16) showed that networks are more than conduits for economic transactions and emerge when people have long-term and recurrent relations.

Both in and out of the mines, the hiboux were involved in two types of activities. As discussed in the previous section, they first marketed vrages. They also smuggled coltan. This was 'untagged' and escaped iTSCi regulations. During their purchases, the hiboux offered higher prices than the trading houses and cooperatives as a means of attracting clients. 
For instance, in October 2013, when the price of coltan was US $\$ 28.8$ o per $\mathrm{kg}$ in Kisengo, hiboux offered to purchase it for US $\$ 35.5^{\circ}$ per $\mathrm{kg}$ (Miners a 2013 Int.). This variation led mineworkers to wonder 'why do hiboux never experience bankruptcy?' (Miners a 2013 Int.). This question implies that, although they cooperated with them, many mineworkers also believed that the hiboux were better off and that these hiboux reaped higher benefits from smuggling than the income the mineworkers earned.

Coltan smuggling also flourished because of variations between prices set in mining areas and those found in the black markets of northern Katanga and South Kivu. In February 2014, one kg of coltan cost US\$37.50 in Bukavu, US $\$ 44$ in Uvira and US\$34 in Kalemie. Each of these prices exceeded that set in the mines, which ranged from US\$28.80 to 40 in Kisengo and Mai-Baridi. Price variations contribute to flourishing black markets, feed 'broader patterns relating to cross-border smuggling' (IPIS 2012: 35) and sustain shadowy commercial networks characteristic of the Great Lakes Region economy (Vlassenroot \& Perrot 2012). In Uvira, many hiboux said on several occasions that they travelled to Bujumbura for 'business' (Hibouxc 2013 Int.), implying that they also traded minerals, especially coltan at higher prices than in northern Katanga and South Kivu.

The hiboux used various means to transport smuggled coltan out of the mining areas. According to inspectors at the division des mines in Kalemie and civil servants at ANR in Misisi and Uvira (Civil servants a 2013 Int.), hiboux used either commercial trucks or motorbikes and transported their parcels mostly by road to Kalemie or via Misisi to Uvira or Bukavu. Some parcels were transported to Uvira by boat from Kalemie. Regardless of the itinerary, the parcels were sometimes divided into small packages and then transported at various intervals (see Figure 2).

Finally, the hiboux negotiated their passage with civil servants in the areas where they travelled. When asked whether they feared being arrested, several hiboux interviewed in Uvira remarked:

Tunajua kuongea na batu ['We know how to talk to people]'. In the areas where we travel, we often buy off some civil servants and obtain official but often fake documents from them. These documents allow us to transport coltan under the name of tin to evade certain taxes and to conceal its value and origin.

Clearly, the hiboux were experienced in negotiating with the civil servants appointed to curb the trade of contraband coltan. Similarly, in their study on taxation at a border crossing between South Sudan and Northern Uganda, Twijnstra et al. (2014) found that norms and rules were constantly re-negotiated between traders and local state officials. 


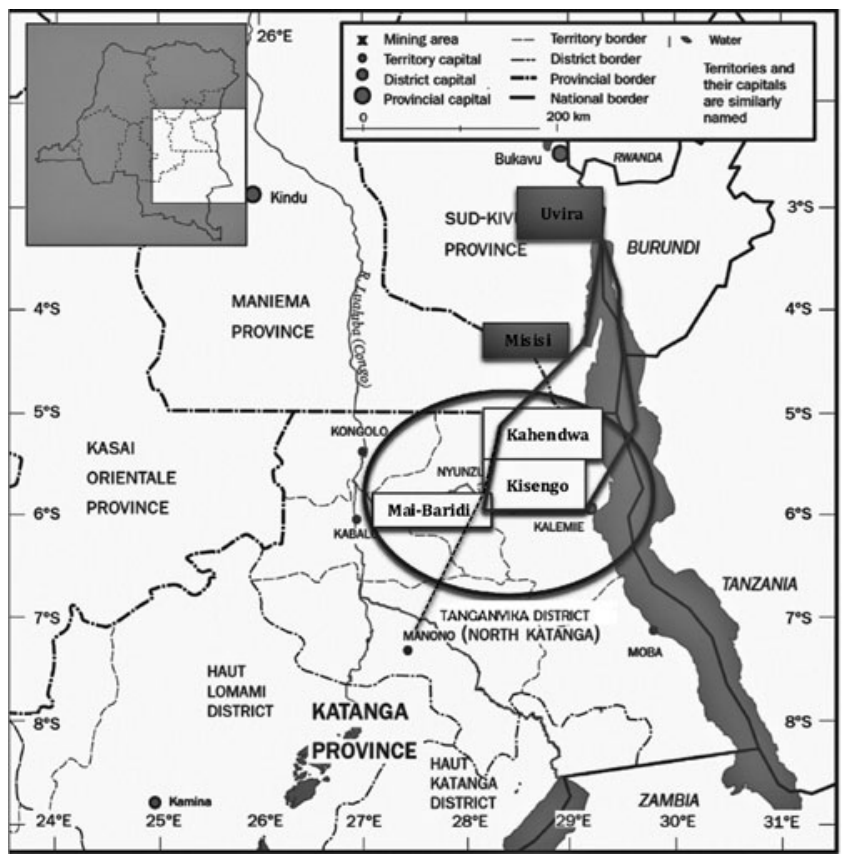

Figure 2. Smugglers' routes. Source. Adapted from De Koning (2010: 2). - - - - Vrages' routes; Coltan smuggling routes.

\subsection{Cheating in dealings with the hiboux}

Cheating and smuggling practices were not only used to breach iTSCi regulations. They were also used against the hiboux themselves. In coltan mines, many hiboux operated within a web of actors. They had antennes to recruit other mineworkers and mine-based négociants or sous-couverts to purchase vrages or to allow them to smuggle coltan. These actors and their social networks formed what can be seen as close social cartels based predominantly on either kinship, friendship or other trust-based relations that allowed them to develop and maintain their economic transactions. Locally, there were therefore many different cartels. This may explain why condemnation of misconduct related to vragage or smuggling coltan rarely occurred in the study area.

Nevertheless, as Rubbers (2009) argues about trust relations, social proximity among Katangese traders does not exclude suspicion, nor does social distance between them necessarily prevent trust.

In fact, smuggling was a two-way street. Within the cartels, miners and mine-based négociants also duped the hiboux. Instead of selling them genuine coltan, they also sold them vrages or other kinds of 
fausses matières. In the eyes of the miners and the local négociants, many hiboux were well off. They were convinced that the hiboux had the opportunity to sell smuggled coltan at better prices, were richer than they were and were exploiting them. Miners and local négociants viewed hiboux as 'big men' and often said that the Hiboux, na Muhindi (Indian in the Kiswahili language), bote ni bamwizi tu [meaning that hiboux and expatriate staff of MMR, predominantly from India, who were working for the company, were all stealing from them] (Miners b 2013 and 2014 Int.). This wording suggests that, although their objectives were not the same, mineworkers and négociants often viewed hiboux and MMR staff as similar groups. At the same time, although social networks were useful, relationships between mineworkers, négociants and hiboux were of subtle 'conniving trust'. Although they could cooperate with the hiboux, miners and négociants were also able to deceive them. Cheating against the hiboux was not perceived as bad behaviour. Instead, the miners and négociants viewed this as an act of resistance against a group of hiboux who exerted control over the coltan black market and were probably exploiting them. This is further illustrated in the following account.

In Kalemie and Uvira, the first author met, on several occasions, four hiboux to whom mineworkers and mine-based négociants had sold vrages (fausses matieres). These hiboux said that this happened regularly. The first author then asked them whether, despite being deceived in this way, the hiboux planned to travel to the mines and were willing to continue their 'clandestine' trade. The hiboux confirmed their intention to continue going to the mining areas and to maintain collaboration with their antennes. Additionally, they stated that they knew the mineworkers and négociants who had deceived them and were convinced that these persons would provide them with an in-kind reimbursement in the form of genuine coltan. Later, interviewed hiboux explained that:

Unless the deceivers left the mining areas, our antennes were responsible for convincing them to provide this reimbursement. However, and more importantly, those deceivers agreed to provide this reimbursement only after being convinced that we would purchase coltan at higher prices than before during their next visit to the mines. (Hiboux d 2013 Int.)

This statement shows that the social networks in which mineworkers and mine-based négociants participated played a key role in this 'economy of cheating' against the smugglers. 


\section{DISCUSSION AND CONCLUSIONS}

This article has elucidated the process of smuggling coltan in northern Katanga, the roles of the key actors involved and the effects of iTSCi measures that have been taken to stop these illegal practices. In the coltan mines, iTSCi aimed to improve the transparency and oversight of the coltan trade. In this way, it intended to address the smuggling of coltan. As part of a regional conflict-free mineral policy, beyond iTSCi, there was an assumption that its activities could contribute to Congolese state- and peace-building in severing armed actors from mineral-based financing. This article does not provide evidence for this assumption in explaining whether the hiboux as 'big men' or other mining actors contributed to the (ongoing) conflicts or how they were related to the armed actors. Yet, the potential of smuggling activities to trigger more conflict requires further investigation.

Noting that people have different responses to policy, this article considered smuggling a primary case of responses circumventing iTSCi policy. This article draws on a sociology of economic life approach, which relies on the idea that economic action is embedded in social networks (Beckert 2007: 9; Hilhorst et al. 2017). By analysing the interactions of artisanal miners, négociants and their social networks in coltan mining areas and between the Congolese regions of northern Katanga and South Kivu, this article concludes that disregarding this social embeddedness explains why iTSCi faced challenges.

Our key findings show that iTSCi technically organised the sale of coltan. It set out a number of regulations and involved official entities (trading houses and cooperatives) in purchasing coltan at the mine level. It also established official selling points (postes d'achat) where coltan was marketed, 'tagged and bagged'. All of these procedures brought a great deal of clarity to an opaque situation where, prior to iTSCi's implementation, a plethora of informal actors intervened in the coltan trade.

For iTSCi, addressing smuggling meant breaking up pre-existing informal trade networks. However, our findings also indicate that these networks were maintained by mineworkers and mine-based négociants, who adapted to the iTSCi regulations. Although iTSCi addressed smuggling through various mechanisms, including 'tagging and bagging' minerals, follow-up committees and reporting 'incidents', these procedures overlooked the actors and social networks in which the mineworkers and négociants were embedded. This web of actors included mineworkers, négociants, local traders, antennes of the hiboux, and sous- 
couverts and helped the hiboux to operate in mining areas. These networks were predominantly based on personal and trust relations, which confirms the importance of a socialised conception of human action in economic transactions (Granovetter 2005).

The present study reveals that the use of social networks was beneficial for mineworkers and négociants. Given that coltan prices varied between mining areas, the politics of price fixing by trading houses and cooperatives differed and the fact that there were variations in coltan purchase prices between northern Katanga and South Kivu provided strong economic incentives for cheating and smuggling. Meanwhile, social networks of mineworkers and négociants served to maintain an opaque circuit around coltan trafficking, as the operations of vragage illustrated. In fact, vragage was condoned by all the participants involved in it. This attitude resembles what Olivier de Sardan (2015: 27) has observed about practical norms in Africa and beyond - i.e. that people involved in practices like 'illegal' payments view these as 'small cheats that are part of the game'.

Thus, the operations of social networks explain why smuggling continued. Smuggling breached and hampered iTSCi regulations. Importantly, this study has also shown that social networks served miners and minebased négociants seeking to cheat the hiboux. Cheating on smugglers is often hidden and under-reported in many studies on smuggling. Smuggling also undermines state effectiveness, as was illustrated by significant coltan smuggling and the involvement of civil servants in facilitating the hiboux' clandestine smuggling operations. In sum, iTSCi has led to an increase in the production of coltan, but not to the elimination of smuggling or a much stronger state.

Utas (2012) has described networks of conflict economies as being powerful, shaped by instability and evolving in a clandestine way, making them flexible, adaptable and under the control of 'big men'. The findings of the present study indicate that these features cannot be restricted to conflict settings alone. Rather, these findings suggest that many of these characteristics can also be found in post-conflict economies such as northern Katanga, where the networks formed around hiboux, who are 'big men' given their financial resources and connections to urban-based black markets, were very flexible in adapting their smuggling activities. However, ordinary miners, who may be seen as 'less powerful' actors, were also involved in these activities. In her seminal research on the gold trade in Kamituga (South Kivu), Geenen (2011: 433) described a similar cheating practice like vragage after finding that the 'commission agents' of gold sellers generated additional 
profits by buying quantities of gold to sell elsewhere or by using their manual scales to cheat when weighing the gold.

Finally, the present study has put to the test the idea of 'enclaves of regulations' as closed and isolated territories where rules regarding coltan trade are applied. It shows that the mining areas where iTSCi policy is implemented are interconnected to the wider region. Therefore, it is necessary to develop both a contextualised and global approach to conflict mineral policies such as iTSCi (Cuvelier et al. 2014: 26), and pay more attention to the logics behind existing informal networks (Van Bockstael \& Vlassenroot 2009) of which miners and négociants are a part. This would help to regulate the old habit of coltan smuggling more effectively.

\section{R E F E R E N C E S}

Autesserre, S. 2012. 'Dangerous tales: dominant narratives on the Congo and their unintended consequences', African Affairs 111: 202-22.

Bayart, J.F. 2000. 'Africa in the world: a history of extraversion', African Affairs 99: 21 7-67.

Beckert, J. 2007. 'The Great Transformation of Embeddedness: Karl Polanyi and the New Economic Sociology', Discussion Paper o7/1. Cologne: Max Planck Institute for the Study of Societies.

Colebatch, H.K. 2009. Policy: concepts in the social sciences. Milton Keynes: Open University Press.

Cuvelier, J., S. van Bockstael, K. Vlassenroot \& C. Iguma. 2014. Analyzing the Impact of the Dodd-Frank Act on Congolese Livelihoods. New York, NY: Social Science Research Council.

De Failly, D. 2001. 'Coltan: pour comprendre...'. L'Afrique des Grands Lacs, Annuaire 2000-2001: 279-306.

Deardorff, A.V. \& W. Stopler. 1990. 'Effects of smuggling under African conditions: a factual, institutional and analytical discussion', Review of World Economics, Vol. 126, Issue 1: 116-141.

De Koning, R. 2010. 'Demilitarizing mining areas in the Democratic Republic of Congo: the case of northern Katanga Province'. Stockholm Peace Research Institute Policy Paper 2010/1. Stockholm: SIPRI.

Diemel, J. \& J. Cuvelier. 2015. 'Explaining the uneven distribution of conflict-mineral policy implementation in the Republic Democratic of Congo: the role of the Katanga policy network (20092011 )', Resources Policy 46: 151-60.

Dijkzeul, D. \& C.I. Wakenge. 2010. 'Doing good but looking bad? Local perceptions of two humanitarian organisations in eastern Democratic Republic of the Congo', Disasters 34: 1139-70.

Ellis, S. \& J. MacGaffey. 1996. 'Research on Sub-Saharan Africa's unrecorded international trade: some methodological and conceptual problems', African Studies Review 39: 19-41.

Garrett, N. \& H. Mitchell. 2009. 'Trading conflict for development: utilising the trade in minerals from eastern DR Congo for development'. London: DFID.

Geenen, S. 201 1. 'Relations and regulations in local gold trade networks in South Kivu, Democratic Republic of Congo', Journal of Eastern African Studies 5: 427-46.

Geenen, S. 2012. 'A dangerous bet: the challenges of formalizing artisanal mining in the Democratic Republic of Congo', Resources Policy 3: 322-30.

Geenen, S. 2016. African Artisanal Mining From the Inside Out: access, norms and power in Congo's gold sector. London: Routledge.

Global Witness. 2009. 'Faced with a gun, what can you do? War and the militarisation of mining in eastern Congo'. London: Global Witness.

Global Witness. 2010. 'The Hill belongs to them. The need for international action on Congo's conflict mineral trade'. London: Global Witness.

Granovetter, M. 1985. 'Economic action and social structure: the problem of embeddedness', American Journal of Sociology 91: $481-510$. 
Granovetter, M. 2005. 'The impact of social structure on economic outcomes', Journal of Economic Perspectives 19: $33^{-} 5^{\circ}$.

Hart, K. 1988. 'Kinship, contract, and trust: the economic organization of migrants in a city slum', in D. Gambetta, ed. Trust: making and breaking cooperative relations. Oxford: Blackwell, pp. 176-93.

Heemskerk, M. 2005. 'Collecting data in artisanal and small-scale mining communities: measuring progress towards more sustainable livelihoods', Natural Resources Forum 29: 82-87.

Hilhorst, D., ed. 2013. Disaster, Conflict and Society in Crises: everyday politics of crisis response. London: Routledge.

Hilhorst, D., G. Van der Haar \& B. Weijs, eds. 2017. People, Aid and Institutions in Socio-economic Recovery: facing fragilities. London: Routledge.

Hilson, G. \& C. Potter. 2003. 'Why is illegal gold mining activity so ubiquitous throughout rural Ghana?', African Development Review 15 : 237-70.

IPIS. 2012. 'The formalisation of artisanal mining in the Democratic Republic of the Congo and Rwanda'. Antwerp: IPIS Report.

iTSCi. 2011. 'iTSCi progress overview: status and budgets'. London: ITRI.

iTSCi. 2013. 'Katanga mining list'. Kalemie: ITRI.

Kibreab, G. 2004. 'Pulling the wool over the eyes of the strangers: refugee deceit and trickery in institutionalized settings', Journal of Refugee Studies 17: 1-26.

MacGaffey, J. 1991. The Real Economy of Zaïre: the contribution of smuggling and unofficial activities to national wealth. Oxford: James Currey.

MacGaffey, J. \& R. Bazenguissa-Ganga. 2000. Congo-Paris: transnational traders on the margins of the law. Oxford: James Currey.

Marcus, G. 1995. 'The emergence of multi-sited ethnography', Annual Review of Anthropology 24: $95^{-117}$.

Meagher, K. 1990. 'The hidden economy: informal and parallel trade in north-western Uganda', Review of African Political Economy 47: 64-83.

Meagher, K. 2010. Identity economics: social networks and informal economy in Nigeria. London: Hebn Publishers.

Mosse, D. 2004. 'Is good policy unimplementable? Reflections on the ethnography of aid policy and practice', Development and Change 35: 639-71.

Müller-Koné, M. 2015. 'Débrouillardise: certifying "conflict-free” minerals in a context of regulatory pluralism in South Kivu, DR Congo', Journal of Modern African Studies 53: 145-68.

Nest, M. 201 1. Coltan. Cambridge: Polity Press.

Olivier de Sardan, J.P. 2015. 'Practical norms: Informal regulations within public bureaucracies (in Africa and beyond)'. Discussion Paper 5, Africa, Power, and Politics Programme. London: Overseas Development Institute.

Radio Okapi. 2016. Fraude minière: 6o tonnes de cassitérite et de coltan saisies au Sud-Kivu, <http://radiookapi.net/economie/2016/02/17>, accessed 20.3.2016.

Raeymaekers, T. 2009. 'Protection for sale? War and the transformation of regulation on the CongoUgandan border', Development and Change 41: $5^{6} 3^{-87}$.

Reno, W. 200o. 'Clandestine economies, violence and states in Africa', Journal of International Affairs 53: $433-59$.

Roitman, J. 2001. 'New sovereigns? Regulatory authority in the Chad Basin', in T. Callaghy, R. Kassimir \& R. Latham, eds. Intervention and Transnationalism in Africa. Global-Local Networks of Power. Cambridge: Cambridge University Press, pp. 240-63.

Rubbers, B. 2009. "We, the Congolese, we cannot trust each other'. Trust, norms and relations among traders in Katanga, Democratic Republic of Congo', British Journal of Sociology 6o: 623-42.

Spittaels, S. 2010. 'The complexity of resource governance in a context of state fragility: an analysis of the mining sector in the Kivus hinterlands'. Antwerp and London: IPIS/International Alert.

Titeca, K. \& T. De Herdt. 2010. 'Regulation, cross-border trade and practical norms in West-Nile, North-Western Uganda', Africa 80: 573-94.

Twijnstra, R., D. Hilhorst \& K. Titeca. 2014. 'Trade networks and the practical norms of taxation at a border crossing between South Sudan and Northern Uganda', Journal of Eastern African Studies, 8: $3^{82-99}$.

Utas, M., ed. 2012. African Conflicts and Informal Power: big men and networks. London: Zed Books.

Van Bockstael, S. \& K. Vlassenroot. 2009. 'From conflict to development diamonds: the Kimberley process and Africa's artisanal diamond mines', Studia Diplomatica LXII: $79-96$.

Vlassenroot, K. \& S. Perrot. 201 2. 'Uganda military entrepreneurialism on the Congo border', in M. Utas, ed. African Conflicts and Informal Power: big men and networks. London: Zed Books. 
Vlassenroot, K., E. Mudinga \& K. Hoffmann. 2016. 'Contesting authority. Armed rebellion and military fragmentation in Walikale and Kalehe, North and South-Kivu'. London: RVI.

Vocke, M. \& N. Oomes. 2003. 'Diamond smuggling and taxation in Sub-Saharan Africa', IMF Working Paper, WP/o3/197.

Vogel, C. \& B. Radley. 2015. 'Fighting windmills in Eastern Congo? The ambiguous impact of the 'conflict minerals' movement', The Extractive Industry and Society 2: 406-10.

Wakenge, C.I. \& D. Hilhorst. 201 7. 'Emergency or durable solution? Coltan mining and cooperatives in Northern Katanga', in D. Hilhorst, B. Weijs \& G. Van der Haar, eds. People, Aid and Institutions in Socio-economic Recovery: facing fragilities. London: Routledge.

\section{N T E R V I E W S}

Boniface Kyungu, Kalemie, 24.6.2013.

Hiboux a, Coltan smuggler, Kalemie, 2.8.2014.

Hiboux b, Coltan smugglers, Misisi, 1 2.2.2014.

Négociants a, Mai-Baridi, and Kisengo, 3.12.2013 and 8.6.2014.

PMH chief and ANR staff members, Kisengo, 12.42014.

Miners focus group a, Matongo (Kisengo), 22.6.2013 and 13.10.2013.

Négociants b, Kisengo, 22.11.2013.

Hiboux c, Uvira and Kalemie, 14.5.2013 and 9.10.2013.

Civil servants a, Kalemie and Misisi, 11.11 .2013 and 10.2.2014.

Miners focus group b, Kisengo and Mai-Baridi, 27.6.2013 and 18.7.2014.

Hiboux d, Coltan smugglers, Kahendwa and Kalemie, 22.5.2013 and 30.11.2013.

iTSCi staff member a, Kahendwa, 20.10.2013.

Civil servants b, Misisi and Uvira, 29.11.2013 and 20.2.2014.

Civil servants c, division des mines, Nyunzu, 7.6.2013.

iTSCi field Coordinator, Nyunzu, 4.6.2014.

iTSCi staff members b, Kalemie and Nyunzu, 7.7.2013 and 5.6.2014. 